\title{
Evaluation of Polymorphisms in IL8 and IL16 Genes in Patients with Acute Coronary Syndrome
}

Lílian Caroliny Amorim Silva, ${ }^{\circledR}$ Romário Martins Araújo, ${ }^{(\oplus)}$ Fábia Carla Silva Soares, ${ }^{1}$ Roberto Pereira Werkhauser, ${ }^{1 \odot}$ Sergio Tavares Montenegro, ${ }^{2}$ Tetsuo Tashiro, ${ }^{3 \oplus}$ Viviane do Carmo Vasconcelos Carvalho, ${ }^{\circledR}$ Silvia Maria Lucena Montenegro' ${ }^{10}$

Instituto Aggeu Magalhães, ${ }^{1}$ Recife, PE - Brazil

Real Hospital Português de Beneficência em Pernambuco (RHP), ${ }^{2}$ Recife, $P E$ - Brazil

Universidade Federal de Pernambuco (UFPE), ${ }^{3}$ Recife, PE - Brazil

\section{Abstract}

Background: Acute coronary syndrome (ACS) is a cardiovascular disease caused by obstruction of coronary arteries by atheromatous plaque. Susceptibility to this disease may be related to genetic variations, such as single nucleotide polymorphisms (SNPs).

Objective: In this study, we evaluated the relationship between SNPs in IL8 (rs4073; -251 A/T) and IL16 (rs11556218; $\mathrm{T} / \mathrm{G}$ ) genes and SCA in a Brazilian population.

Materials and Methods: A sample of 200 patients with ACS and 50 non-ACS patients hospitalized at the Real Hospital Português, Recife - PE, Brazil, and 220 blood donors (donors) was used. Genotyping was carried out by polymerase chain reaction, and DNA sequencing. Statistical analyzes were performed using the Williams G, Chi-square and Kruskal Wallis tests, using the BioEstat 5.0 program, and the data with a value of $p<0.05$ were considered significant.

Results: In the IL8 gene, the AT genotype was the most frequent $(p>0.05)$ in all three groups. In the IL16 gene, genotypic distributions were different between patients with ACS and the donor group $(p=0.002)$, with the most frequent $G$ allele in the second group $(p=0.0052)$. The IL-16 cytokine was higher in donors than in patients with ACS $(p=0.04)$ and the $G(T G+G G)$ allele had higher values of this cytokine $(p=0.01)$.

Conclusions: The results demonstrate the important role of the rs11556218 SNP in IL16 gene in SCA, evidencing that the $\mathrm{G}$ allele may be associated with a decreased risk of the disease. (Int J Cardiovasc Sci. 2020; 33(3):254-262)

Keywords: Cardiovascular Diseases; Acute Coronary Syndrome; Genotype; Dyslipidemia; Diabetes Mellitus; Obesity; Sedentarism.

\section{Introduction}

Acute coronary syndrome (ACS) is a cardiovascular disease (CD) characterized by occlusion of the coronary arteries and most often begins with the rupture of an atherosclerotic plaque in this artery, inducing the formation of a thrombus that occludes partially or totally the vessel. ${ }^{1}$ Among the risk factors that influence its development, the presence of diabetes, dyslipidemia, smoking, obesity, sedentarism, hypertension and stress are highlighted. Age, gender and family history are also considered risk factors. ${ }^{2}$ In addition, genetic factors may also contribute to a greater susceptibility to disease. ${ }^{3}$

Some genetic polymorphisms have already been linked to the risk of developing CDs in specific populations. Interleukin (IL) -8 is produced by a variety

Mailing Address: Silvia Maria Lucena Montenegro

Instituto Aggeu Magalhães - Av. Professor Moraes Rego, s/n. Postal Code: 50.740-465, Recife, PE - Brazil.

E-mail: silvia@cpqam.fiocruz.br 
of cell types involved in atherosclerosis, in addition to being expressed in areas rich in macrophages of atherosclerotic lesions. ${ }^{3-5}$ In addition to a potential role in the initiation and progression of atherosclerosis, IL-8 can also participate in the complications of this process by acting on destabilization of atherosclerotic plaque and specifically on thrombosis. ${ }^{3,4}$ Single nucleotide polymorphism (SNP) in IL8 gene (rs 4073) has been shown to be associated with SCA in different populations. Its frequency is related to a high plasma level of its respective cytokine, which may contribute to an inflammation associated with the infiltration of macrophages and neutrophils, thus providing a substrate for the development of ACS..$^{5,6}$ This SNP has the ability to alter the transcriptional activity of the gene, contributing to the increase of IL-8 cytokine levels. ${ }^{7-9}$

IL-16 is a pleiotropic and immunoregulatory proinflammatory cytokine. ${ }^{10}$ Elevated levels of this cytokine were detected in patients with CAD. ${ }^{11}$ In previous studies, this cytokine is related to the regulation of recruitment and activation of CD4 $+\mathrm{T}$ cells in the inflammatory process of CVDs. ${ }^{12}$

Some studies report that the G mutant allele in its gene (rs11556218) is associated with a significantly increased risk of CDs. ${ }^{13-15}$ The exact role of IL-16 in the pathogenesis of ACS remains unclear, but it is known that the rs11556218 T/G SNP may influence the expression of IL-16 cytokine and alteration of its serum levels may promote the production of other cytokines IL-1, IL-2 and IL- 6 that are involved in the development of ACS. ${ }^{15}$

These findings suggest that SNPs in the IL8 (rs4073) and IL16 (rs11556218) genes may be useful markers of genetic susceptibility to ACS, allowing the identification of high-risk individuals by selecting for more invasive therapies ${ }^{16}$ and closer monitoring.

The lack of uniformity in positive results in several populations is the major problem for the study of genetic association. ${ }^{17}$ Thus, it is necessary to study SNPs in specific populations to identify their association with diseases in a region.

The aim of this study was to evaluate the association between SNPs in the IL8 (rs4073) and IL16 genes (rs11556218) and the risk of developing ACS. In addition it was our intention to compare our blood donor population with other healthy populations from different countries, to contribute to the identification of molecular markers in disease susceptibility.

\section{Materials and Methods}

\section{Study population}

Patients with ACS $(n=200)$ and non-ACS $(n=50)$ are adults of both genders admitted to the Real Hospital Português (RHP), Recife - PE, Brazil. Patients with ACS have their diagnosis performed by the clinical team and laboratory data suggestive of ischemic myocardial injury. Patients with non ACS were admitted to the RHP with other cardiac disease. For both groups, data were collected about the presence of the main risk factors for coronary artery disease such as diabetes mellitus, systemic arterial hypertension and dyslipidemia.

A group of healthy adults $(n=220)$ blood donors with negative diagnosis for infectious and parasitic diseases was also selected. The collection period was from May 2012 to August 2016 for all subjects participating in the study.

The sample size was obtained through the convenience selection of the patients.

The present study was approved by the Research Ethics Committee of RHP (CAEE: 03187512.2.0000.5202) and all individuals signed the Informed Consent Term.

It was decided not to perform ethnic correspondence, since previous studies in Brazilian populations have shown that skin color or self-defined ethnic origins are not considered accurate as biomarkers for ancestry in Brazil. ${ }^{18}$

\section{Genotyping}

Blood was collected in a tube with Ethylene Diamine Tetraacetic Acid (EDTA) and extracted DNA was amplified by the Polymerase Chain Reaction (PCR) method using specific primers and amplification conditions for each SNP (Table 1). As a negative control, reagents without DNA were used. The fragments were visualized on $1 \%$ agarose gel and subjected to DNA sequencing using the ABI 3500xL Genetic Analyzer (Applied Biosystems, USA).

Dosage of inflammatory markers: The cytokines were dosed in the serum through the Human Quantikine ELISA Kit (R\&D Systems, Minneapolis, MN), following the manufacturer's guidelines, using the Enzyme Lynked Immunosorbent Assay (ELISA) method.

\section{Statistical analysis}

The X2 test was used to verify the Hardy-Weinberg equilibrium. Differences between the genotypic 
Table 1 - PCR conditions for the analysis of SNPs in IL8 and IL16 genes

\begin{tabular}{|c|c|c|c|c|}
\hline SNP & Primers & $\begin{array}{l}\text { Amplification } \\
\text { conditions }\end{array}$ & Fragment size & Reference \\
\hline $\begin{array}{l}\text { IL8 } \\
\text { rs4073 } \\
(\mathrm{A} / \mathrm{T})\end{array}$ & $\begin{array}{l}\text { F: 5' CATGATAGCATCTGTAATTAAC } 3^{\prime} \\
\text { 5' CTCATCTTTTCATTATGTCAGA 3' }\end{array}$ & $\begin{array}{l}\text { 1) } 95^{\circ} \mathrm{C}-5 \mathrm{~min} \\
\text { 2) } 95^{\circ} \mathrm{C}-1 \mathrm{~min} \\
\text { 3) } 57^{\circ} \mathrm{C}-1 \mathrm{~min} \\
\text { 4) } 72^{\circ} \mathrm{C}-1 \mathrm{~min} \\
\text { 5) } 72^{\circ} \mathrm{C}-5 \mathrm{~min}\end{array}$ & $348 \mathrm{bp}$ & Andia, et al $(2013)^{19}$ \\
\hline $\begin{array}{l}\text { IL16 } \\
\text { rs11556218 } \\
(\mathrm{G} / \mathrm{T})\end{array}$ & $\begin{array}{c}\text { F: 5' GCTCAGGTTCACAGAGTGTTTCCATA 3' } \\
\text { R: 5' TGTGACAATCACAGCTTGCCTG 3' }\end{array}$ & $\begin{array}{l}\text { 1) } 94^{\circ} \mathrm{C}-4 \mathrm{~min} \\
\text { 2) } 94^{\circ} \mathrm{C}-30 \mathrm{seg} \\
\text { 3) } 60^{\circ} \mathrm{C}-30 \mathrm{seg} \\
\text { 4) } 72^{\circ} \mathrm{C}-30 \mathrm{seg} \\
\text { 5) } 72^{\circ} \mathrm{C}-5 \mathrm{~min}\end{array}$ & $171 \mathrm{bp}$ & $\mathrm{Wu}$, et al $(2011)^{15}$ \\
\hline
\end{tabular}

frequencies were analyzed by the G Williams test and Odds Ratio (OR) with 95\% confidence intervals. The multivariate logistic regression model was used to evaluate the association between genetic polymorphisms and risk factors for ACS. Data were considered statistically significant where $\mathrm{p}<0.05$.

Continuous variables were expressed as means and standard deviation (SD) or medians (cytokine dosages). Categorical variables were expressed in absolute and relative values. Kolmogorov-Smirnov or Shapiro-Wilk tests were used to evaluate normality in the continuous variables. Assuming that the quantitative data did not follow normal distribution, non-parametric tests were applied. Kruskal-Wallis test was used to compare the variation of their concentrations between the groups.

Multivariate analysis was performed using a multivariate logistic regression model to evaluate the association between genetic polymorphisms and risk factors for ACS. In the analysis of all the data was used the program BioEstat 5.0.

\section{Results}

The distributions of the genotypic frequencies are in accordance with the Hardy-Weinberg equilibrium.

The mean age found in the groups with ACS, without ACS and blood donors was $62( \pm 13.0), 58( \pm 18.9)$ and 48 $( \pm 6.3)$ years old, respectively. The male gender was the most frequent in the three groups evaluated $(76.5 \%, 58 \%$ and $85.4 \%$, respectively).
The majority of patients with ACS and non-ACS were non-smokers (69.5\% and $82 \%$, respectively) and nondiabetics (55.5\% and $68 \%$, respectively). Hypertensive patients accounted for $80.5 \%$ of patients with ACS and dyslipidemia was present in $64 \%$ of ACS patients and only $14 \%$ of those without ACS.

Results for the rs4073 (IL8) SNP demonstrated a higher frequency of the AT genotype in all groups analyzed.

For SNP rs11556218 (IL16), the most frequent genotype in all 3 groups was TT. In addition, TG genotype showed higher frequency in blood donor individuals (35.5\%) compared to ACS patients $(21.0 \%$; $\mathrm{p}=0.002$ ). G allele carriers (TG + GG) were more present in donor subjects (36\%) than in patients with ACS (23\%) $(\mathrm{p}=0.0052)$. When comparing the groups with ACS and without ACS, no difference was found in the genotypic distribution (Table 2).

When genetic polymorphisms were evaluated in relation to the main risk factors for ACS (smoking, diabetes, hypertension and dyslipidemias), the IL8 gene showed no association. The rs11556218 SNP in the IL16 gene showed statistical association when analyzed against risk factors hypertension $(p=0.002)$ and dyslipidemias $(\mathrm{p}=0.01)$ (Table 3).

From the results of the genotyping for the polymorphisms and considering the significant association between the SNP rs11556218 in the IL16 gene and SCA, the cytokine IL-16 was dosed. For this, 20 samples from patients with ACS $(\mathrm{TT}=9)$, 
Table 2 - Distribution of genotypic frequencies of SNPs in the IL8 and IL16 genes in the three groups

\begin{tabular}{|c|c|c|c|c|c|c|c|c|}
\hline \multirow{2}{*}{ Genotype } & \multicolumn{2}{|c|}{$\begin{array}{c}\text { ACS } \\
(N=200)\end{array}$} & \multicolumn{2}{|c|}{$\begin{array}{c}\text { NON-ACS } \\
(N=50)\end{array}$} & \multirow{2}{*}{$\begin{array}{c}\text { SCA } x \\
\text { NON-ACS } \\
p\end{array}$} & \multicolumn{2}{|c|}{$\begin{array}{c}\text { DONORS } \\
(\mathrm{N}=220)\end{array}$} & $\begin{array}{c}\text { ACS } x \\
\text { DONORS }\end{array}$ \\
\hline & $\mathbf{N}$ & $\%$ & $\mathbf{N}$ & $\%$ & & $\mathbf{N}$ & $\%$ & $\mathrm{p}$ \\
\hline
\end{tabular}

IL8

(rs4073)

$\begin{array}{lcccccccc}\text { AA } & 46 & 23 & 8 & 16 & 0.46 & 61 & 27.8 & 0.31 \\ \text { AT } & 99 & 49.5 & 29 & 58 & & 111 & 50.4 & \\ \text { TT } & 55 & 27.5 & 13 & 26 & & 48 & 21.5 & \\ \text { AT+TT } & 154 & 77 & 42 & 84 & 0.36 & 159 & 72.3 & 0.31\end{array}$

Alleles

\begin{tabular}{|c|c|c|c|c|c|c|c|c|}
\hline A & 191 & & 45 & & & 233 & & \\
\hline $\mathrm{T}$ & 209 & & 55 & & & 207 & & \\
\hline \multicolumn{9}{|c|}{$\begin{array}{l}\text { IL16 } \\
\text { (rs11556218) }\end{array}$} \\
\hline TT & 154 & 77 & 33 & 66 & 0.30 & 141 & 64 & 0.0026 \\
\hline TG & 42 & 21 & 16 & 32 & & 78 & 35.5 & \\
\hline GG & 4 & 2 & 1 & 2 & & 1 & 0.5 & \\
\hline $\mathrm{TG}+\mathrm{GG}$ & 46 & 23 & 17 & 34 & 0.17 & 79 & 36 & 0.0052 \\
\hline \multicolumn{9}{|l|}{ Alleles } \\
\hline G & 50 & & 18 & & & 80 & & \\
\hline $\mathrm{T}$ & 350 & & 82 & & & 283 & & \\
\hline
\end{tabular}

$(\mathrm{TG}=10),(\mathrm{GG}=1)$ and 20 samples from donor individuals $(\mathrm{TT}=9),(\mathrm{TG}=10)$ and $(\mathrm{GG}=1)$ were used.

The dosages of IL-16 were similar among the three different genotypes in patients with ACS (Figure 1B).

In the donor individuals, the G (TG + GG) allele had higher serum IL-16 levels (701.9 pg/mL) than those with TT genotype $(447.7 \mathrm{pg} / \mathrm{mL})(\mathrm{p}=0.001)$ (Figure $1 \mathrm{~A})$.

The dosage of this cytokine was higher in the donor group (563.0 pg/mL) than in patients with ACS (355.4 pg/ $\mathrm{mL})(\mathrm{p}=0.04)$ (Figure 1C).

The genotypic frequencies of blood donors were also compared to other healthy populations (Table 4). The results show that for the IL8 gene there was similarity ( $p>0.05)$ in the genotypic distribution between the present study and other Brazilian populations of Maranhão ${ }^{20}$ and São Paulo ${ }^{21}$ and the populations of Iran ${ }^{22}$ and Greece. ${ }^{9}$
Regarding SNP rs11556218 in the IL16 gene, there was a difference between the genotype frequencies of China ${ }^{23}$ and $\operatorname{Iran}^{24}$ when compared to the present study $(\mathrm{p}=0.01$ and $<0.0001$, respectively).

\section{Discussion}

The age presents itself as one of the most important risk factors for ACS. ${ }^{28}$ According to Dutra et al., ${ }^{29}$ cardiovascular diseases affect mostly elderly individuals. The mean age found in the present study was 62 years old, corroborating the data obtained by Marino et al., ${ }^{30}$ in a study performed with Brazilian patients with ACS who found a mean age of 63 years old and by Shah et al., ${ }^{31}$ studying Scottish patients with ACS with a mean age of 62 years old. 
Table 3 - Analysis of the association of SNPs in the IL8 and IL16 genes with the risk factors for ACS

\begin{tabular}{llcl}
\hline SNP / risk factors & $\mathbf{p}$ & Odds ratio & IC 95\% \\
\hline IL8 (rs4073) & & & \\
$\quad$ Smoking & 0.39 & 0.73 & $0.36-1.50$ \\
Diabetes & 0.92 & 1.03 & $0.53-2.04$ \\
Hypertension & 0.49 & 0.73 & $0.30-1.79$ \\
$\quad$ Dyslipidemias & 0.31 & 1.43 & $0.72-2.86$ \\
$\begin{array}{l}\text { IL16 (rs11556218) } \\
\quad \text { Smoking }\end{array}$ & 0.94 & 0.97 & $0.46-2.06$ \\
$\quad \begin{array}{l}\text { Diabetes } \\
\text { Hypertension }\end{array}$ & 0.22 & 1.54 & $0.76-3.12$ \\
$\quad$ Dyslipidemias & 0.002 & 0.26 & $0.12-0.62$ \\
\hline $\begin{array}{l}\text { SNP: Single Nucleotide } \\
\text { regression; CI: Confidence Interval. }\end{array}$ & 2.68 & $1.19-6.04$ \\
\hline
\end{tabular}

Besides age, gender is also important in the epidemiology of ACS. According to Maas and Appelman, ${ }^{32}$ cardiovascular diseases, where ACS is included, usually manifest later in women than in men, partly because of differences in exposure to risk and hormonal factors. ${ }^{33,34}$

In our study, males accounted for $76.5 \%$ of ACS patients. Similar data were obtained by Huang et al., ${ }^{15}$ and Bray et al., ${ }^{35}$ who observed the frequency of $80.4 \%$ and $68.0 \%$ of male in ACS patients of their studies, respectively.

Smoking, diabetes, hypertension and dyslipidemias are considered important in increasing the risk for ACS, however, most of the patients in the present study were neither smokers nor diabetics in both groups (with or without ACS). These data corroborate the study by Guedes et al., ${ }^{36}$ in which the majority of Brazilian patients with CD were not smokers (93.3\%). In a study by Vogiatzi et al., ${ }^{5}$ with Greek patients diagnosed with ACS, the majority was not diabetic (64.3\%).

Despite this, diabetes and smoking may not have their importance excluded as risk factors for ACS.

Generally, the majority of patients (with or without ACS) had systemic arterial hypertension. These results corroborate the data obtained from patients with ACS in different countries (Australia, Pakistan, Mexico and Japan) who indicated that the majority of the patients were hypertensive, varying between $56.5 \%$ in Japan and
$68.0 \%$ in the Mexico..$^{14,35,37,38}$ For the Ministry of Health, this disease is responsible for at least $25 \%$ of the deaths due to ACS. ${ }^{39}$

In the present study it was verified that the majority of patients with ACS are dyslipemic (64.0\%), similar data were verified by Feijó et al., ${ }^{40}$ Rodrigues et al., ${ }^{41}$ and Andrade et al., ${ }^{42}$ who studied Brazilian patients with CDs and found that $50.5 \%, 73.9 \%$ and $60.1 \%$, respectively, were dyslipemic.

The data about risks factors reinforce that this disease has a multifactorial character. Thereby the genetic component directly participates in the predisposition to ACS.

Regarding the polymorphism in the IL8 gene (rs4073), we observed a higher frequency of the AT heterozygous genotype in the three groups analyzed. Similarly, in a study by Zhang et al., ${ }^{6}$ a prevalence of AT genotype was $47.4 \%$ in patients with ACS and $45.9 \%$ in the control group.

For the SNP in the IL16 gene (rs11556218), a difference in heterozygous TG genotype frequencies was observed between the group of patients with ACS and the group of blood donors $(p=0.0026)$. In addition, carriers of the $G$ mutant allele were more present in blood donors than in patients with ACS, suggesting that this allele may have a protective action in ACS.

Discordant data were found in a study by Chen et al.. ${ }^{8}$ in which the $\mathrm{G}$ allele was more frequent in patients with ACS (84.9\%) than in the control group (64.2\%). However, the authors point that the lack of success in replicating the positive result in other populations is the main problem for genetic association studies. ${ }^{8}$

When comparing the serum levels of IL-16 cytokine, donor individuals presented higher values than patients with ACS ( $p=0.04)$. In addition, among the blood donors, the $G(T G+G G)$ allele presented higher IL-16 values $(p=0.01)$. These results corroborate the data obtained by Gronberg et al., ${ }^{11,43}$ where the presence of IL-16 on the carotid plaque is associated with a decreased risk of cardiovascular events in studies performed with a Swedish population. This is due to the stabilization of the atherosclerotic plaques, avoiding the ACS disease. ${ }^{11,43}$

The cytokine IL-16 has been described as a proinflammatory cytokine. However, there are few studies supporting its possible anti-inflammatory function, identified by the present study. ${ }^{11,43}$

In addition, one hypothesis for the lack of association found between ACS and non-ACS patients 

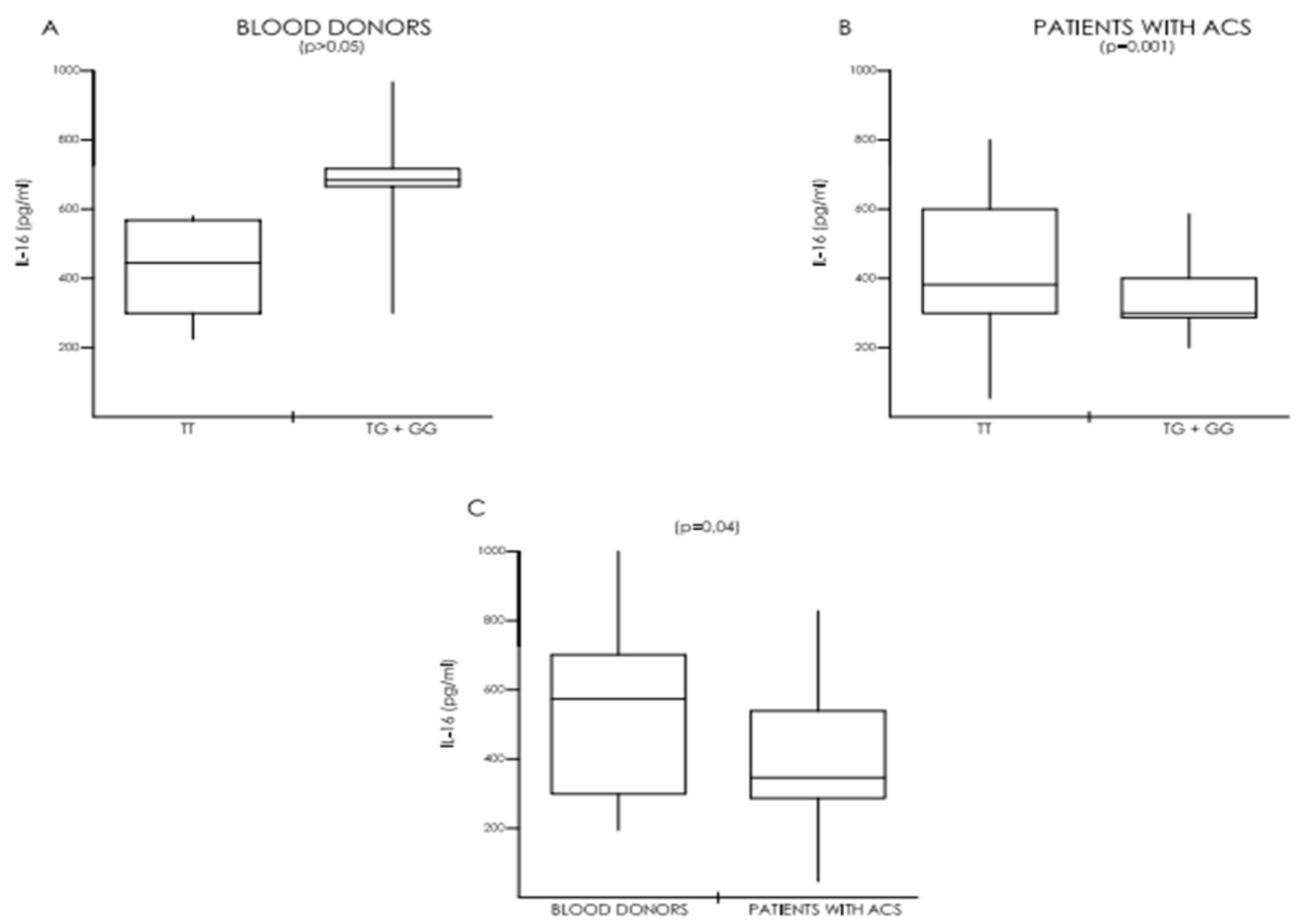

Figure 1 - Box-plot (median and quartiles) of IL-16 dosages in patients with ACS and healthy individuals in different IL16 genotypes. Box-plot (median and quartiles) of IL-16 dosages in patients with ACS and blood donors in different IL16 genotypes. A) Median IL-16 in blood donors $(T T=447.7 \mathrm{pg} / \mathrm{mL} ; T G+G G=709.2 \mathrm{pg} / \mathrm{mL}, p=0.001) ; B)$ Median of IL-16 in patients with ACS (TT=381.4 pg/ml; TG + GG = 314.9 pg/ml, $p=0.288) ; C)$ Median IL-16 in blood donors (563.0 pg/mL) and patients with ACS (355.4 pg/ mL) ( $p=0.04) ; p=$ Mann-Whitney.

is that the SNP in the IL16 gene (rs11556218) is involved with CDs in general, not only with ACS, and further studies are needed, with different populations to answer this question.

An association was found regarding the polymorphism in IL16 gene (rs11556218) and the risk factors hypertension and dyslipidemia. These results corroborate the data found by Chen et al., ${ }^{7}$ with 300 patients with ACS who showed a significant association between the homozygous variant (GG) genotype and the hypertension, diabetic and smoker individuals. In addition, the study by $\mathrm{Wu}$ et al., ${ }^{15}$ with 326 Chinese patients with ACS also found an association between the GG genotype and the disease in hypertensive, diabetic, smoker, obese and dyslipemic individuals.
The analysis of the frequencies of polymorphisms in genes of medical interest for a disease in a population can become an important tool to understand and evaluate the risks that this disease can bring, as well as its morbidity and mortality. The results can be used in future studies of association between these polymorphisms and different pathologies.

Thus, the present study also evaluated a comparison between the frequencies of polymorphisms in the IL8 and IL16 genes of our healthy, blood donor individuals with several other healthy populations from other countries.

Regarding the IL8 polymorphism, a similarity was observed in the genotypic distribution with two Brazilian populations (Maranhão and São Paulo) and two from other countries (Iran and Greece). With respect to the 
Table 4 - Distribution of genotypic frequencies of SNPs in IL8 and IL16 genes in different healthy populations

\begin{tabular}{|c|c|c|c|c|c|c|c|}
\hline \multirow{2}{*}{ SNP } & \multirow{2}{*}{ Country } & \multirow{2}{*}{$\mathbf{N}$} & \multicolumn{3}{|c|}{$\begin{array}{c}\text { Genotype frequencies } \\
\text { n (\%) }\end{array}$} & \multirow{2}{*}{ p } & \multirow{2}{*}{ Reference } \\
\hline & & & AA & AT & TT & & \\
\hline \multirow{10}{*}{$\begin{array}{l}\text { IL8 } \\
\text { (rs4073) }\end{array}$} & $\begin{array}{c}\text { Brazil } \\
\left(\text { Northeast }^{*}\right)\end{array}$ & 220 & $61(27.8)$ & $111(50.4)$ & $48(21.5)$ & 1 & - \\
\hline & $\begin{array}{c}\text { Brazil } \\
\text { (Maranhão) }\end{array}$ & 97 & $22(22.7)$ & $46(47.4)$ & 29 (29.9) & 0.28 & $\begin{array}{l}\text { Frade et al., } \\
\qquad 2011^{20}\end{array}$ \\
\hline & $\begin{array}{c}\text { Brazil } \\
\text { (São Paulo) }\end{array}$ & 126 & $38(30.2)$ & 65 (51.6) & $23(18.2)$ & 0.71 & $\begin{array}{l}\text { Matos et al., } \\
2011^{21}\end{array}$ \\
\hline & Hungary & 75 & $15(20.0)$ & $30(40.0)$ & $30(40.0)$ & 0.01 & $\begin{array}{c}\text { Farkas Jr et al., } \\
\qquad 2011^{25}\end{array}$ \\
\hline & China & 636 & 80 (12.6) & $292(45.9)$ & $264(41.5)$ & $<0.0001$ & $\begin{array}{c}\text { Zhang et al., } \\
2011^{6}\end{array}$ \\
\hline & Turkey & 38 & $8(21.0)$ & $11(29.0)$ & $19(50.0)$ & 0.002 & $\begin{array}{c}\text { Cengiz et al., } \\
2014^{26}\end{array}$ \\
\hline & Iran & 40 & $12(30.0)$ & $17(42.5)$ & $11(27.5)$ & 0.62 & $\begin{array}{l}\text { Khosropanah } \\
\text { et al., } 2013^{22}\end{array}$ \\
\hline & $\begin{array}{l}\text { United } \\
\text { Kingdom }\end{array}$ & 235 & $54(23)$ & $105(44.7)$ & $76(32.3)$ & 0.03 & $\begin{array}{l}\text { Smith et al., } \\
2004^{27}\end{array}$ \\
\hline & Greece & 126 & $38(30.2)$ & 65 (51.6) & $23(18.2)$ & 0.71 & $\begin{array}{c}\text { Georgitsi et al., } \\
2016^{9}\end{array}$ \\
\hline & & & TT & TG & GG & & \\
\hline \multirow{3}{*}{$\begin{array}{l}\text { IL16 } \\
\text { (rs11556218) }\end{array}$} & $\begin{array}{c}\text { Brazil } \\
\left.\text { (Northeast }^{*}\right)\end{array}$ & 220 & $141(64.0)$ & 78 (35.5) & $1(0.5)$ & 1 & \\
\hline & China & 402 & $235(58.4)$ & $151(37.6)$ & $16(4.0)$ & 0.01 & $\begin{array}{l}\text { Tang et al., } \\
2016^{23}\end{array}$ \\
\hline & Iran & 144 & $81(56.3)$ & 48 (33.3) & 15 (10.4) & $<0.0001$ & $\begin{array}{l}\text { Azimzadeh et } \\
\text { al, } 2016^{28}\end{array}$ \\
\hline
\end{tabular}

Brazilian populations, it can be interpreted that despite the intense miscegenation in the country, the genetic characteristics in relation to the SNP evaluated, have been conserved in these populations.

Regarding the SNP in the IL16 gene, no similarities were found when comparing the frequencies of our study with other populations.

The genotypic variety found in the comparison between the results of the present study and other countries leaves us the important observation that further population studies should be carried out in order to understand these similarities or differences found.

\section{Conclusions}

The mutant $G$ allele of rs11556218 polymorphism in the IL-16 gene presents a possible protective action in relation to the development of ACS in the studied population.

Regarding the SNP rs4073 (IL8), no association was found with SCA.

The comparison between the frequency of the SNPs rs4073 (IL8) and rs11556218 (IL16) of the present study and other world populations demonstrated a wide genetic variety. 


\section{Study limitations}

The main limitation of the study refers to the composition of the HEMOPE donor group, since it was not possible to match the ages between this group and the patients. Through literature search, it was possible to observe that the use of blood donors to compose a group of comparisons in genetic studies is adequate, since this group of individuals represents a healthy population in general.

Although it is known that the age for donation ranges from 16 to 69 years, and therefore the age of patients with ACS would be within this age group, during the collection of samples it was observed that the age obtained from the group of was less than 62 years. This fact generated a selection bias.

Therefore, the HEMOPE donor group was used only for comparison of the genotypic and allelic frequencies using the Williams $G$ test and not to establish the odds ratios for the development of ACS.

\section{Acknowledgements}

The authors thank the core-facilities laboratories of Institute Aggeu Magalhães, Fundação Oswaldo Cruz (Fiocruz - PE) for the use of its technology.

\section{Author contributions}

Conception and design of the research: Silva LCA, Werkhauser RP, Carvalho VCV, Montenegro SML. Acquisition of data: Silva LCA, Araújo RM, Soares FCS, Montenegro ST, Carvalho VCV, Montenegro
SML. Analysis and interpretation of the data: Silva LCA, Araújo RM, Werkhauser RP, Tashiro T, Carvalho VCV, Montenegro SML. Statistical analysis: Silva LCA, Werkhauser RP, Tashiro T, Carvalho VCV, Montenegro SML. Obtaining financing: Silva LCA, Carvalho VCV, Montenegro SML. Writing of the manuscript: Silva LCA, Carvalho VCV, Montenegro SML. Critical revision of the manuscript for intellectual content: Silva LCA, Araújo RM, Soares FCS, Werkhauser RP, Montenegro ST, Tashiro T, Carvalho VCV, Montenegro SML.

\section{Potential Conflict of Interest}

No potential conflict of interest relevant to this article was reported.

\section{Sources of Funding}

This study was funded by Proep APQ 1620 4.01/15.

\section{Study Association}

This article is part of the thesis of master submitted by Lílian Amorim, from Instituto Aggeu Magalhães (IAM/ FIOCRUZ).

\section{Ethics approval and consent to participate}

This study was approved by the Ethics Committee of the PROCARDIO/REALCOR under the protocol number 565.461. All the procedures in this study were in accordance with the 1975 Helsinki Declaration, updated in 2013. Informed consent was obtained from all participants included in the study.

\section{References}

1. Silva HS, Moresco RN. Biomarcadores cardíacos na avaliação da síndrome Coronariana Aguda. Scientia Medica. 2011;21(3):132-42

2. Overbaugh KJ. Acute Coronary Syndrome. Am J Nurs. 2009;109(5):42-52.

3. Cavusoglu E, Marmur JD, Yanamadala S, Chopra V, Hedge S, Nazli A, et al. Elevated baseline plasma IL-8 levels are an independent predictor of long-term all-cause mortality in patients with acute coronary syndrome. Atherosclerosis. 2015;242(2):589-94.

4. Apostolakis S, Vogiatzi K, Amanatidou V, Spandidos DA. Interleukin 8 and cardiovascular disease. Cardiovasc Res. 2009;84(3): 353-60.

5. Vogiatzi K, Apotolaskis S, Voudris V, Thomopoilou S, Kochhiadakis, GE, Spandidos DA. Interleukin 8 and Susceptibility to Coronary Artery Disease: a Population Genetics Perspective. J Clin Immunol. 2008;28(4):329-35.

6. Zhang X, Zhang B, Zhang M, Han Y, Zhao Y, Meng Z, et al. Interleukin-8 gene polymorphism is associated with acute coronary syndrome in the Chinese Han population. Cytokine. 2011;56(2):188-91.

7. Zhang M, Fang T, Wang K, Mei H, Lv Z, Wang F, et al. Association of polymorphisms in interleukin-8 gene with cancer risk: a meta-analysis of 22 case-control studies. Onco Targets Ther. 2016 Jun;9:3727-37.

8. Chen J, Ying XM, Huang XM, Huang P, Yan SC. Association between polymorphisms in selected inflammatory response genes and the risk of prostate cancer. Onco Targets Ther. 2016 Jan;9:223-9.

9. Georgitsi MD, Vitoros V, Panou C, Tsangaris I, Aimoniotou E, Gatselis $\mathrm{NK}$, et al. Individualized significance of the $-251 \mathrm{~A} / \mathrm{T}$ single nucleotide polymorphism of interleukin-8 in severe infections. Eur J Clin Microbiol Infect Dis. 2016;35(4):563-70. 
10. Behelgardi A, Hosseini SM, Mohebbi SR, Azimzadeh P, Derakhshani S, Karimi K, et al. A Study on Genetic Association of Interleukin-16 Single Nucleotide Polymorphism (rs1131445) With Chronic Hepatitis B Virus Infection in Iranian Patients. Jundishapur J Microbiol. 2015;8(11):e23411.

11. Grönberg C, Asciutto G, Persson A, Fredrikson GN, Nilsson J, Gonçalves I, et al. Endarterectomy patients with elevated levels of circulating IL16 have fewer cardiovascular events during follow-up. Cytokine. 2016 Sep;85:137-9.

12. Chen W, Zhu WL, Zhang SY, Chen LF, Wang X, Chen TB, et al. Increased Monocytic Expression of Urokinase Receptor in Acute Coronary Syndrome: A Potential Marker of Clinical Instability. Heart. 2012;98(2):E181.

13. Chen Y, Huang H, Pan LA, Zhou B, Zhang L, Leng Z, et al. IL-16 rs11556218 gene polymorphism is associated with coronary artery disease in the Chinese Han population. Clin Biochem. 2011;44(13):1041-4.

14. Huang H, Zeng Z, Zhang L, Liu R, Li X, Qiang O. The association of interleukin-16 gene polymorphisms with susceptibility of coronary artery disease. Clin Biochem. 2013;46(3):241-4.

15. Wu J, Wang Y, Zhang Y, Li L. Association Between Interleukin-16 Polymorphisms and Risk of Coronary Artery Disease. DNA Cell Biol. 2011;30(5):305-8.

16. Tong Z, Li Q, Zhang J, Wei Y, Miao G, Yang X. Association between interleukin 6 and interleukin 16 gene polymorphisms and coronary hear disease risk in a Chinese populationn. J Int Med Res. 2013;41(4):1049-56.

17. Chanock SJ, Thomas G. The devil is in the DNA. Nat Genet. 2007;39(3):283-4

18. Parra FC, Amado RC, Lambertucci JR, Rocha J, Antunes CM, Pena SD. Color and genomic ancestry in Brazilians. Proc Natl Acad Sci U S A. 2003;100(1):177-82.

19. Andia DC, Letra A, Casarin RCV, Casati MZ, Line SRP, Souza AP. Genetic analysis of the IL-8 gene polymorphism (rs4073) in generalized agressive periodontitis. Arch Oral Biol. 2013;58(2):211-7.

20. Frade AF, Oliveira LC, Costa DL, Costa CH, Aquino D, Van Weyenbergh $\mathrm{J}$, et al. TGFB1 and IL8 gene polymorphisms and susceptibility to visceral leishmaniasis. Infect Genet Evol. 2011;11(5):912-6.

21. Matos MF, Lourenço DM, Orizaka CM, Bajerl JA, Noguti MA, Morelli VM. The role of IL-6, IL- 8 and MCP-1 and their promoter polymorphisms IL-6 -174GC, IL-8 -251AT and MCP-1 -2518AG in the risk of venous thromboembolism: A case-control study. Thromb Res. 2011;128(3):216-20.

22. Khosropanah H, Sarvestani EK, Mahmoodi A, Golshah M. Association of IL-8 (-251 A/T) Gene Polymorphism with Clinical Parameters and Chronic Periodontitis. J Dent (Tehran). 2013;10(4):312-8.

23. Tang YJ, Wang JL, Xie KG, Lan CG. Association of interleukin 16 gene polymorphisms and plasma IL16 level with osteosarcoma risk. Sci Rep. 2016;6:34607.

24. Azimzadeh P, Romani S, Mohebbi SR, Kazemian S, Vahedi M, Almasi $S$, et al. Interleukin-16 (IL-16) gene polymorphisms in Iranian patients with colorectal cancer. J Gastrointestin Liver Dis. 2011;20(4):371-6.

25. Farkas GJ, Hofner P, Balog A, Takács T, Szabolcs A, Farkas G, Mándi Y, et al. Relevance of transforming growth factor-beta1, interleukin-8, and tumor necrosis factor-alpha polymorphisms in patients with chronic pancreatitis. Eur Cytokine Netw. 2007;18(1):31-7.

26. Cengiz M, Yasar DG, Ergun MA, Akyol G, Ozenirler S. The Role of Interleukin-6 and Interleukin-8 Gene Polymorphisms in Non-Alcoholic Steatohepatitis. Hepat Mon. 2014;14(12):e24635.
27. Smith KC, Bateman AC, Fussell HM, Howell WM. Cytokine gene polymorphisms and breast cancer susceptibility and prognosis. Eur J Immunogenet. 2004;31(4):167-73.

28. Gawryszewski VP, Souza MF. Mortality due to cardiovascular diseases in the Americas by region, 2000-2009. Sao Paulo Medical Journal. 132(2):105-10.

29. Dutra DD, Duarte MC, Albuquerque KF, Lima AlS, Santos JS, Souto HC. Cardiovascular disease and associated factors in adults and elderly registered in a basic health unit. J Fundam Care Online. 2016;8 (2):4501-9.

30. Marino BC, Marcolino MS, Reis Júnior RS, França AL, Passos PF, Lemos TR, et al. Epidemiological Profile and Quality Indicators in Patients with Acute Coronary Syndrome in Northern Minas Gerais - Minas Telecardio 2 Project. Arq Bras Cardiol. 2016;107(2):106-15.

31. Shah AS, Anand A, Sandoval Y, Lee KK, Smith SW, Adamson PD, Chapman AR, et al. High-sensitivity cardiac troponin I at presentation in patients with suspected acute coronary syndrome: a cohort study. Lancet. 2015;386(10012):2481-8.

32. Maas AH, Appelman YE. Gender differences in coronary heart disease. Neth Heart J. 2010;18(12):598-602.

33. Magee RL, Lacerda ECT, Borges GFB, Daher GAG, Macedo RG, Nogueira ACC, Brinck AV. Síndrome Coronariana Aguda: uma revisão. Rev Med Saude Brasilia 2012;1(3):174-89

34. Mendelsohn ME, Karas RH. Estrogen and the blood vessel wall. Curr Opin Cardiol. 2018;33(1):95-100.

35. Bray JE, Stub D, Ngu P, Cartledge S, Straney L, Stewart M, et al. Mass Media Campaigns' Influence on Prehospital Behavior for Acute Coronary Syndromes: An Evaluation of the Australian Heart Foundation's Warning Signs Campaign. J Am Heart Assoc. 2015;4(7):e001927.

36. Guedes RF, Melo TE, Lima AP, Guimarães AL, Moreira NBB, Garcia PG.. Análise do perfil lipídico e dos fatores de risco associados a doenças cardiovasculares em acadêmicos da área da saúde de Juiz de Fora. HU Revista. 2016;42(2):159-64.

37. Satti HS, Hussain S, Javed Q. Association of Interleukin-6 Gene Promoter Polymorphism with Coronary Artery Disease in Pakistani Families. Scientific World J. 2013 Dec;2013:538365.

38. Vargas-Alarcon G, Vallejo M, Posadas-Romero C, Juarez-Rojas JG, Martinez-Rios MA, Peña-Duque MA, et al. The -974C >A (rs3087459) gene polymorphism in the endothelin gene (EDN1) is associated with risk of developing acute coronary syndrome in Mexican patients. Gene. 2014;542(2):258-62.

39. Brasil. Ministério da Saúde. Envelhecimento e saúde da pessoa idosa. 2006. [Cited in 2018 Feb 12]. Available from: http://189.28.128.100/dab/ docs/publicacoes/cadernos_ab/abcad19.pdf]

40. Feijó MKEF, Lutkmeier R, Ávila CW, Rabelo ER. Fatores de risco para doença arterial coronariana em pacientes admitidos em unidade de hemodinâmica. Rev Gauch Enfer. 2009;30(4):641-47.

41. Rodrigues PH, Oliveira MB, Cazelato L, Chagas EF, Quitério RJ. A influência dos fatores de risco para doenças cardiovasculares sobre a modulação autonômica cardíaca. Rev Aten Saúde. 2016;14(49):34-40.

42. Andrade SM, Telino CJ, Sousa AC, Melo EV, Teixeira CC, Teixeira CK. Oliveira JL, et al. Baixa Prevalência de Eventos Adversos Maiores à Ecocardiografia sob Estresse Físico. Arq Bras Cardiol. 2016;107(2):116-23.

43. Gronberg, C., Bengtsson, E., Fredrikson, G. N., Nitulescu, M., Asciutto, G., Persson, A, Bjorkbacka. Human Carotid Plaques With High Levels of Interleukin-16 Are Associated With Reduced Risk for Cardiovascular Events. Stroke. 2015;46(10):2748-54. 